\title{
TEMPERATURE-DEPENDENT NONEQUILIBRIUM CARRIER DYNAMICS IN EPITAXIAL AND BULK 4H-SiC
}

\author{
K. Neimontas ${ }^{\text {a }}$, T. Malinauskas ${ }^{a}$, R. Aleksiejūnas ${ }^{a}$, R. Yakimova ${ }^{b}$, and \\ K. Jarašiūnas ${ }^{a}$ \\ ${ }^{a}$ Institute of Materials Science and Applied Research, Vilnius University, Sauletekio 9, LT-10222 Vilnius, Lithuania \\ E-mail: karolis.neimontas@ff.vu.lt \\ ${ }^{\mathrm{b}}$ Department of Physics and Measurement Technology, Linkoping University, SE-581 83 Linkoping, Sweden
}

Received 7 November 2005

\begin{abstract}
We present the results of nonequilibrium carrier dynamics in highly excited $4 \mathrm{H}$-SiC crystals $-n$-type epilayers and semiinsulating wafer. Picosecond four-wave mixing measurements have been carried out at various grating periods, excitation energies, temperatures, and have provided the bipolar diffusion coefficients and lifetimes of nonequilibrium carriers. We show that the phonon scattering contributes mainly to the carrier mobility in 100-300 K temperature range, providing $\mu \sim T^{-1.5}$ dependence. Lattice heating was observed, and it dominated in refractive index modulation at $T<100 \mathrm{~K}$, thus precluding the studies of carrier dynamics at low temperatures.
\end{abstract}

Keywords: four-wave mixing, carrier mobility, thermal grating, $4 \mathrm{H}-\mathrm{SiC}$

PACS: 72.20.Jv, 78.47.+p

\section{Introduction}

$\mathrm{SiC}$ is commonly recognized as a semiconductor material suitable for fabrication of various electronic and optoelectronic devices to be used for high-power, high-temperature, high-frequency, and high-resistanceto-radiation applications $[1,2]$. Such devices often operate at high carrier densities, therefore it is important to determine the carrier plasma parameters under adequate conditions. Non-destructive monitoring of carrier plasma parameters at high injection conditions is possible by using nonlinear optical techniques, which explore monitoring of light-induced absorption or refractive index modulation by free carriers $[3,4]$. Timeresolved four-wave mixing (FWM) [4] is a more advantageous technique as it provides possibility of nondestructive studies of carrier transport in wide range of excitation as well as simple separation of diffusion and recombination processes. Moreover, optical carrier injection at different wavelengths with quantum energies above the band gap $E_{\mathrm{g}}$ makes it possible to vary indepth resolution, to reach high nonequilibrium carrier density, and to study carrier density-dependent photoelectric processes [5].

In this work, we applied the picosecond FWM technique for studies of carrier dynamics in epitax- ial $4 \mathrm{H}-\mathrm{SiC}$ layers and in a semi-insulating (SI) crystal in a $10-300 \mathrm{~K}$ temperature range. We determined the temperature dependence of bipolar carrier mobility, $\mu_{\mathrm{a}} \sim T^{-1.5}$, in the range of $100-300 \mathrm{~K}$ at different photoexcited carrier densities. At temperatures below $100 \mathrm{~K}$, we observed strong contribution of lattice heating to refractive index modulation. The latter effect created a temperature grating, which was competing with the free carrier one, and precluded the studies of carrier dynamics at low temperatures. The lattice heating was attributed to increased nonradiative recombination rate at lower temperatures and temperature-dependent specific capacity.

\section{Samples}

The experiments were performed on $n$-type weakly doped epitaxial $4 \mathrm{H}-\mathrm{SiC}$ layers grown by chemical vapour deposition (CVD) or sublimation techniques on various substrates (see Table 1). Carrier dynamics was also studied in a bulk semi-insulating $4 \mathrm{H}-\mathrm{SiC}$ crystal, grown by high temperature CVD (HTCVD). For excitation of the thicker epilayers and the bulk crystal, we used the third harmonics of the YAG:Nd laser $(\lambda=$ $355 \mathrm{~nm}$ ), since its absorption coefficient is $210 \mathrm{~cm}^{-1}$ and the light excites a depth of $\alpha^{-1} \approx 48 \mu \mathrm{m}$ [6]. In the 
Table 1. Sample labelling and properties.

\begin{tabular}{cccccc}
\hline Sample & Type & $\begin{array}{c}\text { Doping } \\
\text { level }\left(\mathrm{cm}^{-3}\right)\end{array}$ & $\begin{array}{c}\text { Growth } \\
\text { technique }\end{array}$ & $\begin{array}{c}\text { Thickness } \\
\text { of the layer }\end{array}$ & Substrate \\
\hline P939 & $n$ & $10^{16}$ & CVD & $\sim 35 \mu \mathrm{m}$ & Heavily doped $(n$-type $)$ \\
S256 & $n$ & $6 \cdot 10^{15}$ & Sublimation & $\sim 30 \mu \mathrm{m}$ & SI \\
S265 & $n$ & $2 \cdot 10^{15}$ & Sublimation & $\sim 13 \mu \mathrm{m}$ & SI \\
JT090 & SI & - & HTCVD & $\sim 400 \mu \mathrm{m}$ & - \\
\hline
\end{tabular}

given case, the diffraction signal reveals the processes in effective depth, comparable to the epilayer thickness of 30-35 $\mu \mathrm{m}$. To minimize the thickness of photoexcited layer to a few $\mu \mathrm{m}$, two samples (S265 and P939) were photoexcited by using the fourth harmonics of the laser $(\lambda=266 \mathrm{~nm})$.

\section{Experimental technique}

Temperature-dependent carrier dynamics in $\mathrm{SiC}$ samples was investigated using the non-degenerate FWM technique in the thin grating regime. The samples were excited by the interference pattern of two 25 ps duration laser beams at 355 or $266 \mathrm{~nm}$ wavelength $\left(h \nu=3.51\right.$ or $\left.4.68 \mathrm{eV}>E_{\mathrm{g}}=3.26 \mathrm{eV}\right)$, which created a sinusoidal free carrier distribution $N(x)=$ $N_{0}+\Delta N \cdot \sin (2 \pi x / \Lambda)$ with the period $\Lambda$ and refractive index modulation by free carriers $\Delta n_{\mathrm{FC}}(x, t) \sim$ $\Delta N(x, t)$. The exciting light was absorbed correspondingly in $\alpha^{-1} \sim 48 \mu \mathrm{m}$ or $1-2 \mu \mathrm{m}$ thick surface layer of material, thus creating a layer of ambipolar carrier plasma of density up to $10^{18}-10^{19} \mathrm{~cm}^{-3}$. A delayed probe pulse at $1064 \mathrm{~nm}$, to which $\mathrm{SiC}$ epitaxial layers were transparent, was used to monitor the instantaneous diffraction efficiency of the grating $\eta=I_{\mathrm{D}} / I_{\mathrm{T}}$ (here $I_{\mathrm{D}}$ is the diffracted and $I_{\mathrm{T}}$ is the transmitted probe beam intensity), which was proportional to the square of refractive index modulation, i.e. $\eta(t) \sim$ $\Delta n_{\mathrm{FC}}^{2}(t)=\left(n_{\mathrm{eh}} \cdot \Delta N\right)^{2}$ [4]. The calculated magnitude of index change by one electron-hole pair in $4 \mathrm{H}-\mathrm{SiC}$ at $1064 \mathrm{~nm}$ wavelength is $n_{\mathrm{eh}}=-7 \cdot 10^{-22} \mathrm{~cm}^{3}$. The carrier grating decay time $\tau_{\mathrm{G}}$ is obtained by an exponential fit of diffraction efficiency decay kinetics $\eta \sim \exp \left(-2 t / \tau_{\mathrm{G}}\right)$. The grating is erased by carrier recombination and lateral diffusion processes, therefore $\tau_{\mathrm{G}}$ can be expressed through ambipolar diffusion coefficient $D_{\mathrm{a}}$ and carrier recombination time $\tau_{\mathrm{R}}$ [4]:

$$
\frac{1}{\tau_{\mathrm{G}}}=\frac{1}{\tau_{\mathrm{R}}}+\frac{4 \pi^{2} D_{\mathrm{a}}}{\Lambda^{2}}
$$

The decay of free-carrier grating with carrier density $N(x, t)$ is described by

$$
\begin{aligned}
\frac{\partial N(x, t)}{\partial t}= & D_{\mathrm{a}}(N) \frac{\partial^{2} N(x, t)}{\partial x^{2}}-\frac{N(x, t)}{\tau_{\mathrm{R}}} \\
& -B N^{2}(x, t)-C N^{3}(x, t)+G(x, t) .
\end{aligned}
$$

Here $C$ is the Auger recombination coefficient, $B$ is the bimolecular recombination coefficient, and $G(x, t)=$ $\alpha I(x, t) /(h \nu)$ is the carrier generation function.

Assuming the high photoexcited carrier density, quantum excess energy $\left(h \nu-E_{\mathrm{g}}\right)$, and the mechanism of nonradiative recombination in $\mathrm{SiC}$, a local heating of the sample must be taken into account. It is known that the thermal refractive index modulation $\Delta n_{T}=\partial n / \partial T \cdot T(x, t)$ can emerge in highly excited Si crystals $[7,8]$. The temperature distribution $T(x, t)$ in the silicon carbide sample is described by the following equation:

$$
\begin{aligned}
\frac{\partial T(x, t)}{\partial t}- & D_{T} \frac{\partial^{2} T(x, t)}{\partial x^{2}}=\frac{N(x, t)}{\rho C_{p}} \\
& \times\left(h \nu C N^{2}(x, t)+\sigma_{\mathrm{eh}} I(x, t)\right) \\
& +\frac{\alpha}{\rho C_{p}} \frac{h \nu-E_{\mathrm{g}}}{h \nu} I(x, t) .
\end{aligned}
$$

Here the terms on the right side are the sources of heat generation due to Auger recombination, free-carrier absorption, and overload of $E_{\mathrm{g}}, \rho$ is the density of $\mathrm{SiC}$, $C_{p}$ is the specific heat, $\sigma_{\mathrm{eh}}$ is the cross-section of free carrier absorption, and $D_{T}$ is the thermal diffusion coefficient [7].

The total refractive index modulation is due to polarizability by electron-hole pairs $\Delta n_{\mathrm{FC}}$ and to the temperature change $\Delta n_{T}$,

$$
\Delta n=\Delta n_{\mathrm{FC}}+\Delta n_{T} .
$$

The refractive index change due to increased temperature $\Delta n_{T}$ is positive whereas the refractive change due to carrier excitation $\Delta n_{\mathrm{FC}}$ is negative, therefore the simultaneous presence of two mechanisms drastically cancel the diffraction efficiency. The magnitude 


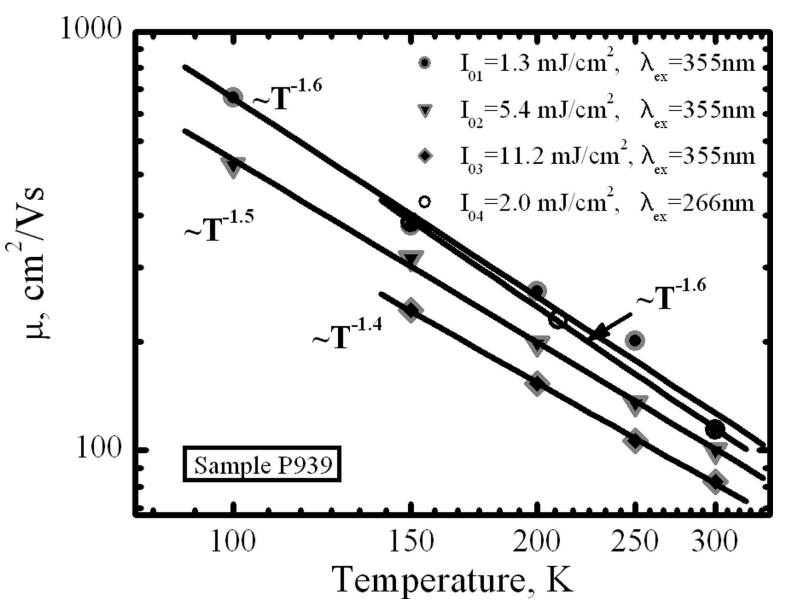

Fig. 1. Bipolar carrier mobility dependence on temperature at different photoexcitation intensities in weakly doped $n$-type epitaxial 4H-SiC sample P939.

of these two optical nonlinearities, being dependent on carrier density, varies with excitation, time, ambient temperature, therefore these processes will be analysed numerically and experimentally in this work. The decay time of the thermal grating is described by equation (5) with thermal diffusion coefficient $D_{T}=k /\left(\rho \cdot C_{p}\right)$ ( $k$ is the thermal conductivity),

$$
\tau_{T}=\frac{\Lambda^{2}}{4 \pi^{2} D_{T}} .
$$

\section{Results and discussion}

We have measured grating decay kinetics at different grating periods $\Lambda$ (in the range from 2.7 to $14 \mu \mathrm{m}$ ), excitation intensities, and temperatures (10-300 K). Using the set of measured grating kinetics at various periods and the corresponding grating decay times $\tau_{\mathrm{G}}$, we determined the bipolar diffusion coefficients $D_{\mathrm{a}}$ and carrier lifetimes by the help of Eq. (1). The bipolar mobility values $\mu_{\mathrm{a}}$ were obtained from the Einstein relation $D_{\mathrm{a}}=(k T / e) \mu_{\mathrm{a}}$. In Fig. 1 we show the decrease of bipolar mobility with temperature in the range of 100 $300 \mathrm{~K}$ at various excitation intensities. The measured temperature dependences $\mu \sim T^{-A}$ were found to be similar to those typical for phonon (lattice) scattering mechanism [9] and provided the index value $A$ from 1.4 to 1.6 for nonequilibrium carrier density, varying from $\sim 5 \cdot 10^{17}$ to $\sim 10^{19} \mathrm{~cm}^{-3}$. The slope values of $A$ from 1.3 to 1.9 were found for electron mobility in $n$-type $4 \mathrm{H}-\mathrm{SiC}$ in $100-300 \mathrm{~K}$ range $[10,11]$ and $A$ from 1.5 to 2 for the hole mobility in $p$-type epilayer in 200-300 K range [12]. We note that our experiments differ from those in [10-12] as intercarrier scattering may contribute at the used nonequilibrium carrier densities [13]. Assuming that diffusion coefficient of holes is much smaller than that of electrons $\left(D_{\mathrm{e}} \gg D_{\mathrm{h}}\right)$, the relationship $D_{\mathrm{h}}=2 D_{\mathrm{h}}$ is valid and points out that the measured temperature dependence reveals nonequilibrium hole mobility at high carrier density. Our data provide $\mu_{\mathrm{h}}=60 \mathrm{~cm}^{2} /(\mathrm{V} \cdot \mathrm{s})$ value at room temperature, which is in good agreement with Hall measurements in low doped $4 \mathrm{H}-\mathrm{SiC}$ epilayers with hole mobility in the range of $60-120 \mathrm{~cm}^{2} /(\mathrm{V} \cdot \mathrm{s})[12,14]$. We attribute the decrease of bipolar mobility with excitation (Fig. 1) to the band gap renormalization and its contribution to nonequilibrium carrier transport through the spatially modulated carrier plasma $[5,13]$. The similar decrease of $D_{\mathrm{a}}$ value with respect to expected one $D_{\mathrm{a}}=4.3 \mathrm{~cm}^{2} / \mathrm{s}$ was also observed in highly excited $n$-type $4 \mathrm{H}-\mathrm{SiC}$ epilayers and provided hole mobility of $55 \mathrm{~cm}^{2} /(\mathrm{V} \cdot \mathrm{s})$ [13]. We also note that carrier lifetimes decrease with temperature from $10 \mathrm{~ns}(300 \mathrm{~K})$ to $2 \mathrm{~ns}$ $(100 \mathrm{~K})$.

We found the similar temperature dependence of bipolar mobility in differently grown layer sample S256. The measurements revealed the typical dependence $\left(\mu \sim T^{-1.5}\right)$ in the temperature domain 140$300 \mathrm{~K}$ at similar excitation conditions $\left(\lambda_{\mathrm{ex}}=355 \mathrm{~nm}\right.$, $\left.I_{0}=1.3 \mathrm{~mJ} / \mathrm{cm}^{2}\right)$. The determined parameters $\left(D_{\mathrm{a}}\right.$ and lifetime) in this sample were found to be slightly lower than those in the CVD grown layer P939. This can be attributed to higher concentration of defects. Namely, the values of $D_{\mathrm{a}}=2.1 \mathrm{~cm}^{2} / \mathrm{s}$ and $\mu=$ $80 \mathrm{~cm}^{2} /(\mathrm{V} \cdot \mathrm{s})$ in the $\mathrm{S} 256$ sample and the corresponding values of $D_{\mathrm{a}}=2.8 \mathrm{~cm}^{2} / \mathrm{s}$ and $\mu=110 \mathrm{~cm}^{2} /(\mathrm{V} \cdot \mathrm{s})$ in the P939 sample have been measured. The carrier lifetimes also decrease at lower temperatures: $\sim 4 \mathrm{~ns}$ at $T=300 \mathrm{~K}$ and $\sim 2 \mathrm{~ns}$ at $T=100 \mathrm{~K}$. At the present time the concentration and origin of defects are not known, and spectroscopic studies of these layers are in progress.

In Fig. 2 we show the temperature dependence of bipolar mobility in semi-insulating crystal (sample JT090). The constant but lower slope of it $\left(\mu \sim T^{-1.2}\right)$ in a wide temperature range (10-300 K) points out that the scattering mechanism by phonons is strongly influenced by ionised impurity scattering, which is expected to be dominant only at low temperatures in a compensated material [12]. For more accurate analysis of this result, complementary Hall mobility measurements will be performed.

The measurements of grating kinetics at temperatures $T<100 \mathrm{~K}$ revealed an effect which has not been observed earlier in $\mathrm{SiC}$ crystals. In Fig. 3(a) the 


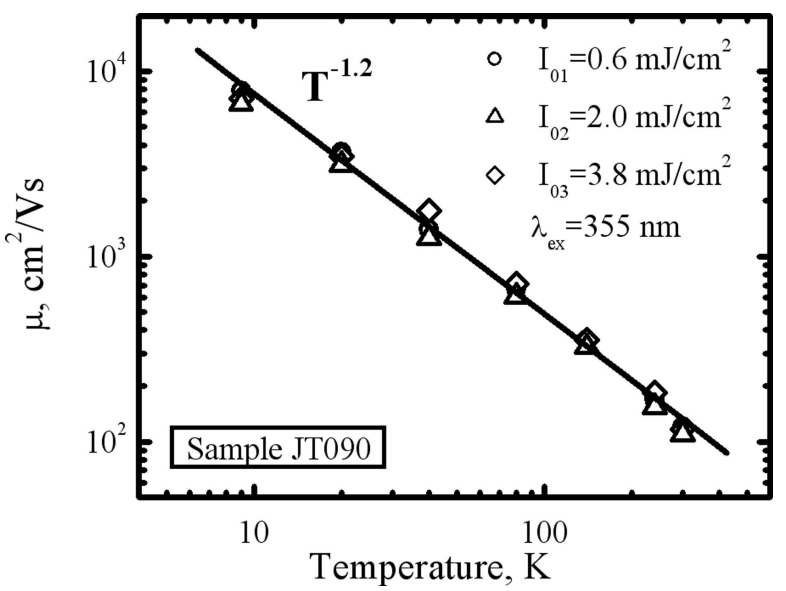

Fig. 2. Bipolar carrier mobility dependence on temperature at different photoexcitation intensities in semi-insulating $4 \mathrm{H}-\mathrm{SiC}$ crystal.

grating kinetics measured in $n$-type epitaxial layer (sample P939) at different temperatures are presented. The grating decay is single exponential and becomes faster with temperature decreasing from 300 to $100 \mathrm{~K}$. Here, because of increasing carrier mobility, the diffusive grating decay time $\tau_{\mathrm{D}}=\Lambda^{2} /\left(4 \pi^{2} D\right)$ becomes shorter at the used small grating period of $2.7 \mu \mathrm{m}$. At lower temperatures, the kinetics become non-exponential and reveal competition with another mechanism of refractive index modulation. We attribute this effect to refractive index modulation by temperature $\Delta n_{T}$, previously observed in highly excited Si crystals [7]. We have found that the contribution of coexisting temperature grating in $\mathrm{SiC}$ is increasing at lower temperature, and diffraction efficiency of it is comparable with that of free carrier grating. The dip in diffraction reveals the competition of two refractive index modulation mechanisms with the opposite signs (see Eq. (4)); at later time, the diffraction on thermal grating dominates. Its decay is governed by thermal diffusion coefficient (see Eq. (5)), which is smaller than the bipolar carrier diffusion coefficient, therefore the final decay part is rather slow. Taking the thermal grating decay time of $1 \mathrm{~ns}$ (Fig. 3(a), $T \leq 75 \mathrm{~K}$ ) and using Eq. (5), we have estimated the thermal diffusion coefficient $D_{T}=$ $1.8 \mathrm{~cm}^{2} / \mathrm{s}$, which is close to that reported in the literature [15]. At larger grating periods, the contribution of thermal grating to the total diffraction efficiency is observed at later times (at $\Delta t>1 \mathrm{~ns}$, see Fig. 3(b)), as the carrier grating modulation is less erased by diffusion and persists for a longer time.

For preliminary quantitative analysis of two coexisting mechanisms of refractive index modulation, we solved Eqs. (2) and (3), which provided one dimensional spatial evolution of $N(x, t)$ and $T(x, t)$, i. e. along the grating vector $x$. More precise numerical
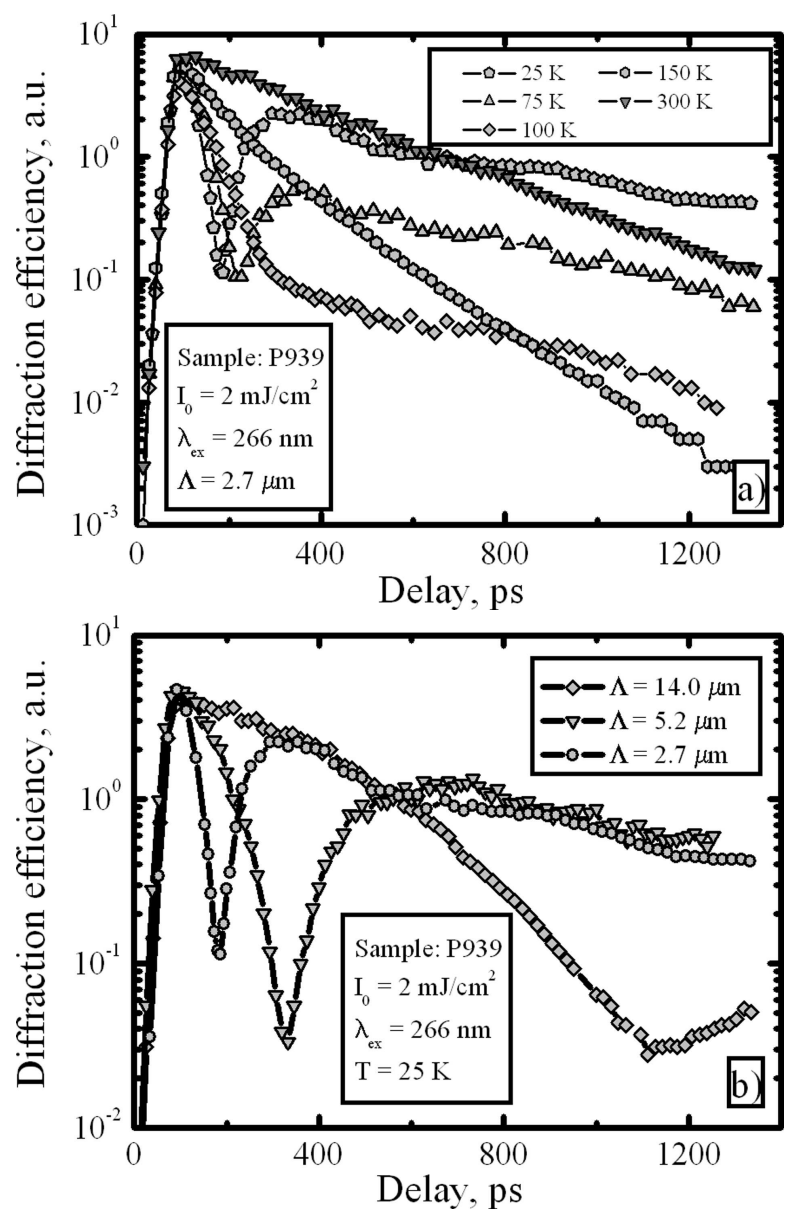

Fig. 3. Kinetics of grating diffraction efficiency measured at (a) different temperatures for the fixed grating period of $2.7 \mu \mathrm{m}$ and (b) for different grating periods at fixed temperature. In both cases, the same photoexcitation conditions were used: $I_{0}=2 \mathrm{~mJ} / \mathrm{cm}^{2}$, $\lambda_{\mathrm{ex}}=266 \mathrm{~nm}$.

analysis requires two-dimensional solution of carrier and temperature dynamics in nonhomogeneously excited layer. In the simplified model, we neglected sample heating by free carrier absorption and used the constant $B$ and $C$ values (see Eq. (2)) [16], while the $C_{p}$ value is known to be temperature dependent [15]. A value of $\partial n / \partial T$, to our knowledge, is not determined for $\mathrm{SiC}$, therefore we have used that of silicon, equal to $2 \cdot 10^{4} \mathrm{~K}^{-1}$ [8]. The calculated kinetics at $T=$ $75 \mathrm{~K}$ for some grating periods are shown in Fig. 4(a). The numerical data are in qualitative agreement with the experimental results (see Fig. 3(b)), providing a dip in diffraction efficiency and its shift to later times for larger periods. Moreover, the calculations also explained the observed increasing contribution of thermal grating at lower temperatures. Assuming that the specific heat decreases at lower temperatures, one may expect the increasing lattice heating with decreasing sample temperature. The numerical modelling for two 

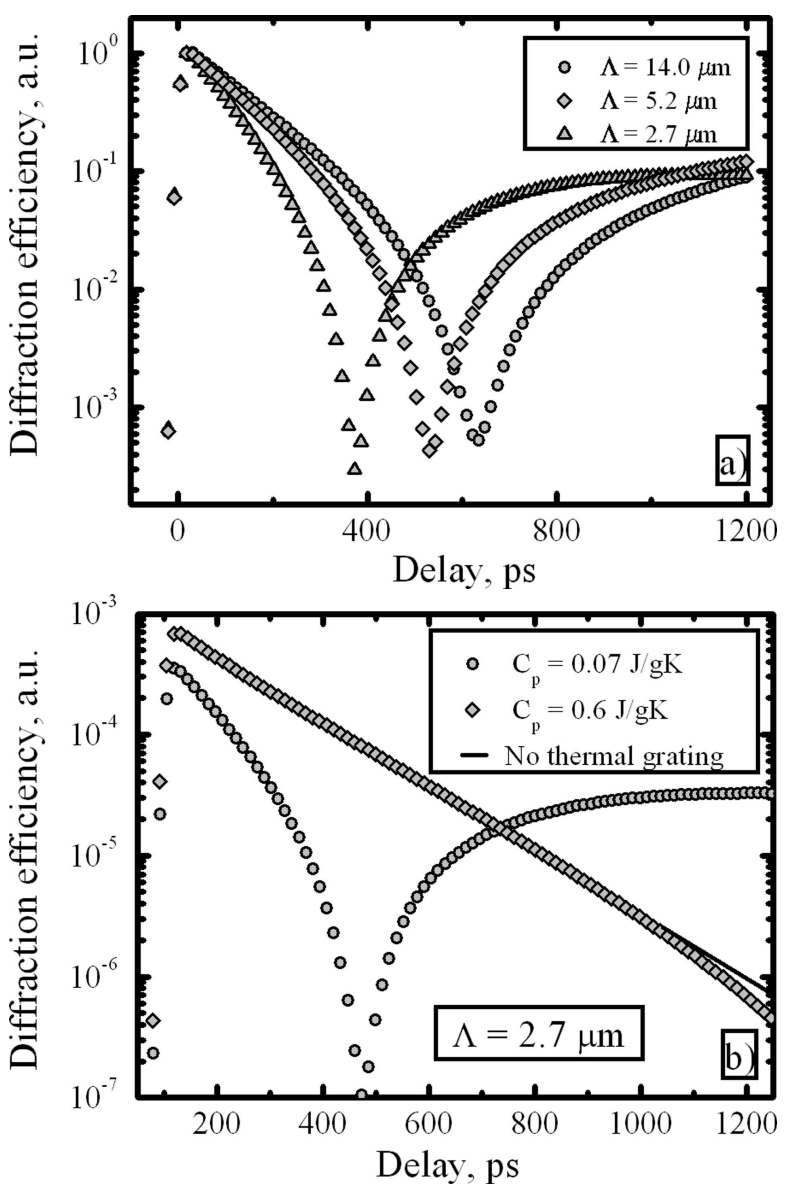

Fig. 4. The calculated diffraction efficiency kinetics (a) for different grating periods $\Lambda$ and (b) for two specific heat values $C_{p}$. Parameters used in numerical calculations: $\lambda_{\mathrm{ex}}=266 \mathrm{~nm}, \tau_{\mathrm{R}}=10 \mathrm{~ns}$, $C=7 \cdot 10^{-31} \mathrm{~cm}^{6} / \mathrm{s}, B=1.5 \cdot 10^{-12} \mathrm{~cm}^{3} / \mathrm{s}, \rho=3.2 \mathrm{~g} / \mathrm{cm}^{3}$, $D_{T}=1 \mathrm{~cm}^{2} / \mathrm{s}, D=3 \mathrm{~cm}^{2} / \mathrm{s}, \partial n / \partial T=2 \cdot 10^{-4} \mathrm{~K}^{-1}$, $n_{\mathrm{eh}}=-7 \cdot 10^{-22} \mathrm{~cm}^{3}$.

specific heat values, $C_{p 1} \approx 0.07 \mathrm{~J} /(\mathrm{g} \cdot \mathrm{K})$ at $75 \mathrm{~K}$ and $C_{p 2}=0.6 \mathrm{~J} /(\mathrm{g} \cdot \mathrm{K})$ at $300 \mathrm{~K}[15]$, has confirmed that refractive index modulation by nonequilibrium carrier plasma $\left(\left(n_{\mathrm{FC}}\right)\right.$ is dominant at higher temperatures, but the increasing temperature grating gradually masks its role (see Fig. 4(b)). The observed effect can be used for investigation of thermal properties of $\mathrm{SiC}$ in a wide temperature range, thus providing supplementary technique for thermo-optical studies [17].

Measurements of grating kinetics performed in S265 sample $\left(\Lambda=2.7 \mu \mathrm{m}, \lambda_{\text {ex }}=266 \mathrm{~nm}, I_{0}=2 \mathrm{~mJ} / \mathrm{cm}^{2}\right)$ also revealed the formation of a temperature grating. We note that in this layer the temperature-induced refractive index change is higher: the kinetics measured at $T<150 \mathrm{~K}$ are as strongly influenced by the thermal grating as those in the sample P939 at $T<100 \mathrm{~K}$. This indirectly points to additional source of heat in a sublimation-grown sample, which has more structural defects that may serve as centres of nonradiative re- combination. On the contrary, the semi-insulating sample at $355 \mathrm{~nm}$ excitation has exhibited the lowest contribution of the thermal grating and has allowed measurements of carrier dynamics in the temperature range from 10 to $300 \mathrm{~K}$.

\section{Summary}

Nonequilibrium carrier grating kinetics at various periods and sample temperatures allowed us to determine the bipolar diffusion coefficients and lifetimes of nonequilibrium carriers in $4 \mathrm{H}-\mathrm{SiC}$ layers. We show that in $n$-type layers the phonon scattering determines the temperature dependence of bipolar carrier mobility in 100-300 $\mathrm{K}$ temperature range $\left(\mu \sim T^{-1.5}\right)$ while in semi-insulating crystal the ionised impurity scattering contributes as well and leads to lower mobility values and lower slope $\left(\mu \sim T^{-1.2}\right)$. The observed lattice heating precluded the studies of carrier dynamics at low temperatures. We confirmed the contribution of the thermal grating to diffraction by numerical modelling, and determined experimentally the thermal diffusion coefficient $D_{T}=1.8 \mathrm{~cm}^{2} / \mathrm{s}$ at $10-75 \mathrm{~K}$.

\section{References}

[1] S.G. Muller, R. Eckstein, J. Fricke, R. Hofmann, R. Horn, H. Mehling, and O. Nilsson, Mater. Sci. Forum 623, 264-268 (1998).

[2] C. Brylinski, in: European Space Components Conference, pp. 217-224 (2000).

[3] P. Grivickas, J. Linnros, and V. Grivickas, Mater. Sci. Forum 338-342, 671-674 (2000).

[4] K. Jarasiunas, in: UV Solid-State Light Emitters and Detectors, NATO Science Series in Mathematics, Physics and Chemistry, Vol. 144 (Kluwer Academic Publishers, 2004), pp. 93-109.

[5] K. Neimontas, R. Aleksiejūnas, M. Sūdžius, K. Jarašiūnas, and J.P. Bergman, Mater. Sci. Forum 483-486, 413-416 (2005).

[6] S.G. Sridhara, R.P. Devaty, and W.J. Choyke, J. Appl. Phys. 84(5), 2963-2964 (1998).

[7] J. Vaitkus, K. Jarašiūnas, E. Gaubas, L. Jonikas, R. Pranaitis, and L. Subačius, IEEE J. Quantum Electronics 22(8), 1298-1306 (1986).

[8] H.J. Eichler, F. Massmann, E. Biselli, K. Richter, M. Glotz, L. Konetzke, and X. Yang, Phys. Rev. B 36(6), 3247-3253 (1987).

[9] J. Singh, Electronic and Optoelectronic Properties of Semiconductor Structures (Cambridge University Press, Cambridge, 2003). 
[10] T.T. Mnatsakanov, M.E. Levinshtein, L.I. Pomortseva, and S.N. Yurkov, Semicond. Sci. Technol. 17, 974-977 (2002).

[11] T.T. Mnatsakanov, L.I. Pomortseva, and S.N. Yurkov, Semiconductors 35(4), 394-397 (2001).

[12] H. Matsuura, M. Komeda, S. Kagamihara, H. Iwata, R. Ishihara, T. Hatakeyama, T. Watanabe, K. Kojima, T. Shinohe, and K. Arai, J. Appl. Phys. 96(5), 27082715 (2004).

[13] P. Grivickas, J. Linnros, and V. Grivickas, Mater. Sci. Forum 338-342, 671-674 (2000).
[14] W.J. Shatter, , H.S. Kong, G.H. Negley, and J.W. Palmour, Inst. Phys. Conf. Ser. 137, 155 (1994).

[15] Advanced Materials Engineered to Perform (Rohm and Haas Company, 2000).

www. cvdmaterials.com.

[16] A. Galeckas, J. Linnros, V. Grivickas, U. Lindefelt, and C. Hallin, Appl. Phys. Lett. 71(22), 3269-3271 (1997).

[17] V.C. Anjos, M.J.V. Bell, E.A. Vasconcelos, E.F. Silva, A. Andrade, R. Franco, M.P. Castro, I. Esquef, and R. Faria, Mater. Sci. Forum (to be published in 2006).

\title{
TEMPERATŪRINIAI NEPUSIAUSVIRŲJŲ KRŪVININKŲ DINAMIKOS TYRIMAI 4H SILICIO KARBIDE
}

\author{
K. Neimontas ${ }^{\text {a }}$, T. Malinauskas ${ }^{\text {a }}$, R. Aleksiejūnas ${ }^{a}$, R. Yakimova ${ }^{\text {b }}$, K. Jarašiūnas ${ }^{\text {a }}$ \\ a Medžiagotyros ir taikomuju mokslu institutas, Vilniaus universitetas, Vilnius, Lietuva \\ ${ }^{\mathrm{b}}$ Linčiopingo universitetas, Linčiopingas, Švedija
}

\section{Santrauka}

Pirmą kartą temperatūriniams nepusiausvirųjų krūvininkų dinamikos matavimams pritaikyta keturbangio maišymo metodika. Išmatuotos bipolinio krūvininkų judrio (difuzijos koeficiento) ir gyvavimo trukmès priklausomybès nuo temperatūros silpnai legiruotuose $n$ tipo $4 \mathrm{H}-\mathrm{SiC}$ epitaksiniuose sluoksniuose (100-300 K) ir didžiavaržyje kristale (10-300 K). Iš išmatuotų priklausomybių $\sim T^{-3 / 2}$ išaiškèjo, kad pagrindis krūvininkų sklaidos mechanizmas epitaksiniuose sluoksniuose yra sklaida fononais visame matuotos temperatūros intervale $(100-300 \mathrm{~K})$ ir skirtingo fotosuža- dinimo sąlygomis $\left(\sim 5 \cdot 10^{17}-\sim 10^{19} \mathrm{~cm}^{-3}\right)$. Didžiavaržyje kristale pastebèta, kad krūvininkų sklaidą stipriai veikia jonizuotos priemaišos $\left(\sim T^{-1,2}\right)$. Eksperimentiniais ir skaitmeninio modeliavimo rezultatais parodyta, kad, esant žemai temperatūrai $(T<$ $100 \mathrm{~K}$ ), kristalinès gardelès kaitinimas dèl nespindulinès laisvųjų krūvininku rekombinacijos ir energijos perviršio, susidarančio žadinant kristalą šviesos kvantu $h \nu>E_{\mathrm{g}}$, sukelia temperatūrinę lūžio rodiklio moduliaciją, kuri daro stiprią itaką difrakcijos efektyvumo kinetikai. Apskaičiuotas šiluminis difuzijos koeficientas $D_{T}=1,8 \mathrm{~cm}^{2} / \mathrm{s}$. 